\title{
Mikoviny Sámuel esztergomi utcafelmérése és csapadékvíz-elvezetési javaslata
}

\author{
Csima Péter - Deák Antal András
}

DOI: $10.30921 / G K .72 .2020 .5 .3$

Absztrakt: Mikoviny Sámuel 1748-ban felkérést kapott Esztergom szabad királyi város tanácsától a város utcáinak felmérésére és a csapadékvizek biztonságos elvezetéséhez szükséges burkolatlejtések meghatározására. 17 mérési ponton határozta meg a szomszédos pontok közötti relatív magasságkülönbségeket és a vízelvezetéshez szükséges terepalakitás mértékét. A belváros belsố utcáinak és az egykori Piactérnek a szerkezete és méretei az azóta eltelt 270 év alatt sem változtak, a jelenlegi utca- és térburkolatok örzik a 18. század közepén Mikoviny javaslatai alapján megvalósult lejtéseket.

Abstract: The council of the free royal town of Esztergom invited Sámuel Mikoviny in 1748 to survey the streets of the town and to determine the slopes of coverage in order to drain the rainwater safely. He calculated the relative height differences between seventeen neighbouring measuring points and determined the size of reshaping the terrain for draining the water. The pattern and size of the inner streets and the one-time Market Square of the town did not change in the last 270 years. The present street and square coverage preserves the slope conditions built according to Mikoviny's recommendations in the middle of the 18th century.

Kulcsszavak: Esztergom, Mikoviny Sámuel, csapadékvíz-elvezetés

Keywords: Esztergom, Sámuel Mikoviny, drainage of rainwater

\section{Előzmények}

1747-ben kezdték meg Esztergom királyi város - a mai Belváros - utcáinak kövezését. A következô évben a városi tanács felkérte az ekkor Almáson (ma Dunaalmás) dolgozó, azaz a városhoz közel tartózkodó Mikoviny Sámuelt, hogy mérje fel az utcákat, és adjon javaslatot a csapadékvizek biztonságos elvezetéséhez. Az országos hírú „geometra et architectus” a megbízást 1748 nyarán teljesítette annak ellenére, hogy abban az idôszakban rengeteg munkája halmozódott fel. A Királyi Kamara megbízása alapján egyidejúleg foglalkozott az almási malmok múködőképessé tételével és az általa tervezett komáromi cölöphíd építésének irányításával. Június 22-én írt levelében panaszkodott gróf Illésházy Józsefnek arról, hogy mennyire túlterhelt, és ezért a gróf számára vállalt feladatokat nem tudja teljesíteni (Deák 1987). Esztergom város vezetése július 23-án kocsit küldött érte Almásra és szállást biztosított számára a fogadóban. A munkáról és a város azzal kapcsolatos intézkedéseirôl a városi jegyzőkönyvek Tóth által közreadott (2011 és 2014) feljegyzései adtak elôször hírt. A felmérés és javaslat német nyelvú leírását 2018-ban a Komárom-Esztergom Megyei Levéltárban megtaláltuk (MNL KEML), majd azt a Mikoviny Sámuel építészeti és tájalakító tevékenységét ismertetô könyv bemutatta (Csima 2019). Mikoviny életrajzaiban ez a megbízatása korábban nem szerepelt.

\section{A felmérés leírása és vázlatrajza}

A múszeres felmérés északi határa a Lốrinc-kapunál, déli és keleti határa a városároknál volt. Mai elnevezésük szerint a Kossuth Lajos utca, a IV. Béla király utca, a Bottyán János utca, a Jókai Mór utca, a Deák Ferenc utca és a Széchenyi tér vízelvezetô folyókáinak, illetve burkolatának a csapadékvizek elvezetéséhez szükséges lejtéseit állapította meg. A megbízás alapján 17 pontnál határozta meg a szomszédos mérési pontok közötti relatív magasságkülönbségeket. Ahol szükségesnek tartotta, ott megadta az adott tereppont mélyítésének („f”, „r" és „l” pontoknál) vagy éppen magasításának (,i” és „p” pontoknál) javasolt mértékét. A vizek lefolyásához szükséges lejtések meghatározásához természetesen a pontok közötti távolságokat is meg kellett mérnie. A felmért pontok magasságkülönbségeirôl és a javaslatokról hét bekezdésben szöveges leírást adott és vázlatrajzot készített.

A leírásban Mikoviny megnevezi a Sándor báró, a Dezsôffy órnagy és a nádorhelyettes házánál, a Szent Anna utcánál és a Buda utcánál (Ofner Gasse), valamint a Piactéren (Platz) és a két városkapunál (Thor) lévő mérési pontokat. A felmérés leírásának részlete látható az 1. ábrán. Az irat

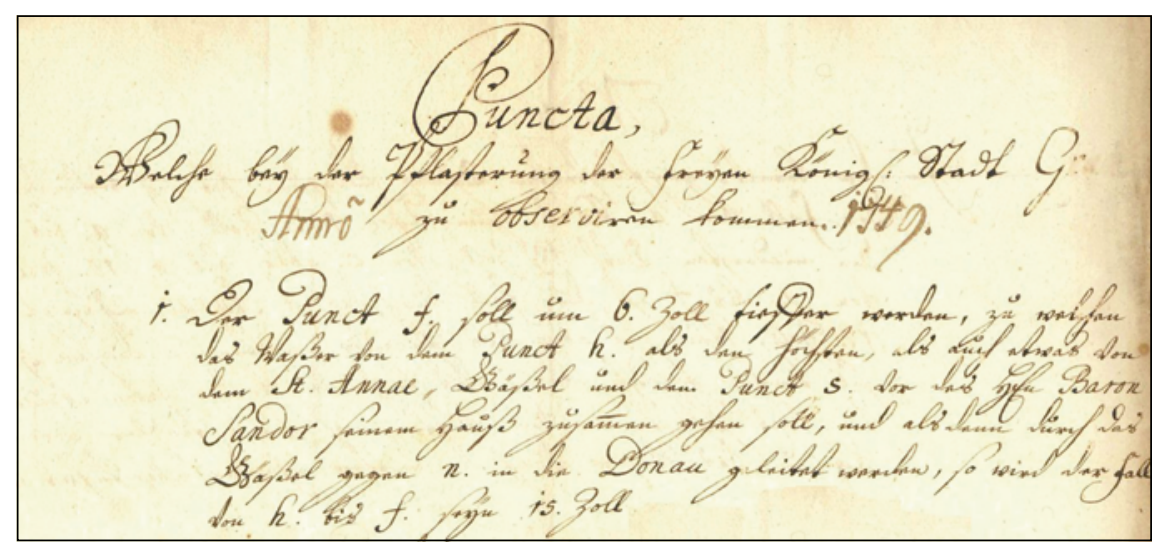

1. ábra. A felmérés és javaslat leirásának címe és elsố bekezdése (MNL KEML, részlet) 
mellékleteként Mikoviny által készített rajz eddig nem került elő, ezért a leírás adatai alapján rekonstruáltuk annak valószínú tartalmát (2. ábra).

A Belváros utcáit végigjárva azonosítottuk a felmérés pontjait, irányait. Az utcák vonalvezetését és lejtésviszonyait azóta északon a Lốrinc-kapu és délen a Budai kapu környékén jelentősen átalakították. Természetesen nagyobb terepalakítások történtek a szegélyeken is, amikor betemették a városárkot, és amikor árvízvédelmi töltést emeltek a Kis-Duna mentén. A belsô utcák és az egykori Piactér szerkezete és méretei azonban nem változtak. A jelenlegi utca- és térburkolatok ôrzik a 18. század közepén Mikoviny javaslatai alapján megvalósult lejtéseket (3-10. ábrák).

\section{Esztergom szabad királyi város utcáinak megvizsgált pontjai}

(Az MNL KEML IV.1001a. jelzetü leírás forditása, kiegészitve a bécsi mértékegységgel megadott magassági adatok átszámitásával. ${ }^{1}$ )

1.Az „f” pontnak 6 hüvelykkel [ $=15,8 \mathrm{~cm}]$ mélyebben kell lennie ahhoz, hogy a víz úgy a „h” ponttól, amint a Szt. Anna utcától és az „s” ponttól, Sándor báró házától összefolyhasson, és az utcán keresztül „n” felé, a Dunába vezethetô legyen. Így a „h” ponttól az „f”-ig az esés 15 hüvelyk [=39,5 cm] lesz.

2.Az „s” ponttól a „g”-ig az esés 103 hüvelyk [=271,3 cm].

3.A víz a legmagasabban lévô „h” ponttól, a nádorhelyettes házánál lévô „r” ponton keresztül folyik, ahol a folyókát 12 hüvelykkel [=31,6 cm] mélyíteni kell. Az „i" pontot 6 hüvelykkel [ $=15,8 \mathrm{~cm}]$ magasítani kell, ezáltal az „r) 30 hüvelykkel [=79,0 cm] lesz alacsonyabban a „h”-nál, az „i” pedig 40 hüvelykkel [=105,4 cm] az „r."-nél.

4.A már leburkolt „k” pont a Tér legmélyebb pontja, ahol az összes burkolat és a folyókák összefutnak, és az „i"-tôl a „k”-ig 31 hüvelyk [=81,7 cm], az „o”-tól a „k”-ig 26

${ }^{1}$ Egy bécsi hüvelyk $=2,634 \mathrm{~cm}$

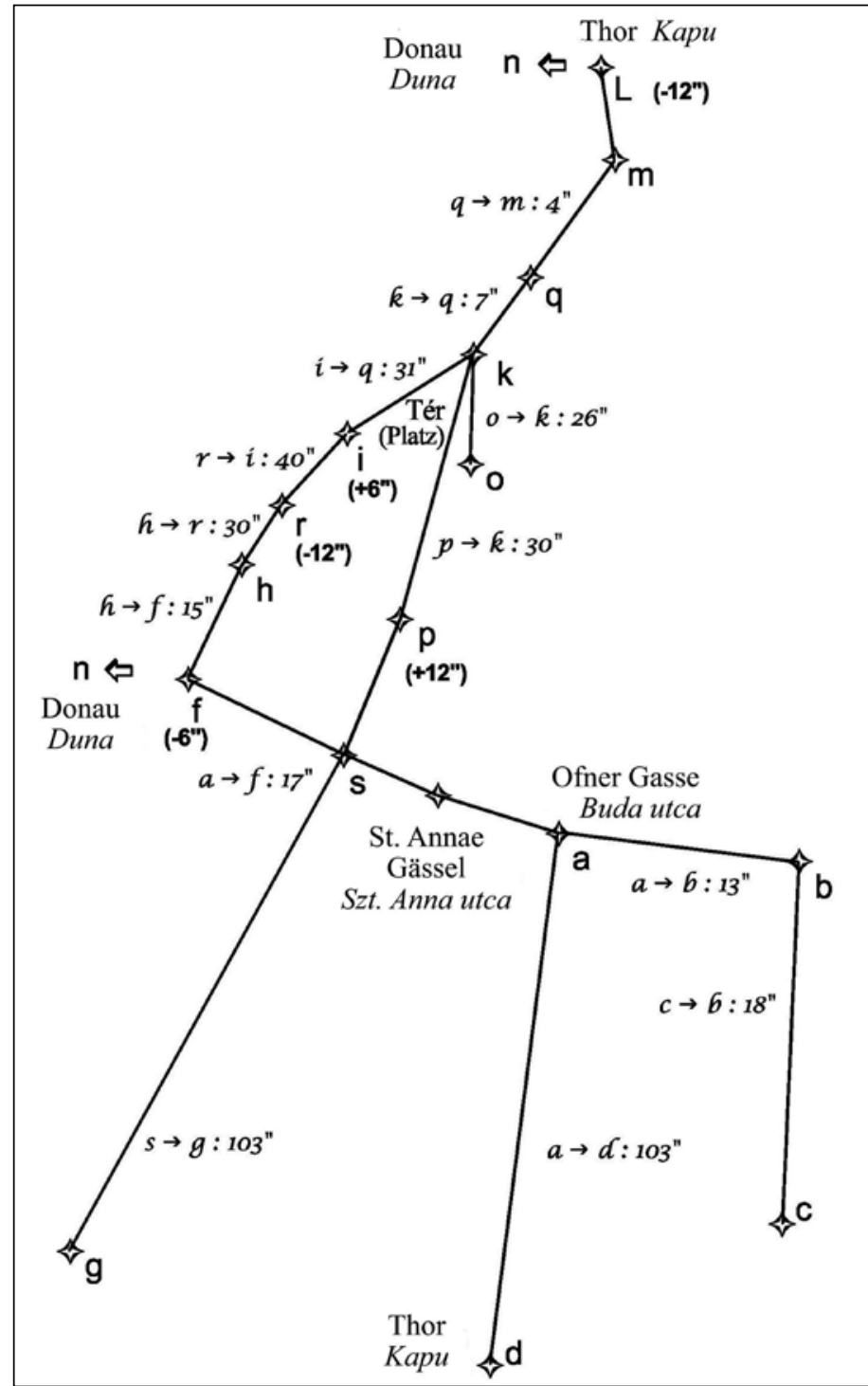

2. ábra. Rekonstruált vázlatrajz Mikoviny Sámuel 1748. évi esztergomi felmérésének leirása alapján (mérési pontok betüjelekkel; terepmélyitési és magasitási javaslatok; mérési pontok közötti meglévó, illetve tervezett lejtések mértéke)

hüvelyk [=68,5 cm] az esésük. Megjegyzés: Amennyiben „i " úgy marad, mint jelenleg, akkor „h”-tól ,i"-ig 70 hüvelyk [=184,4 cm], ,i'"-tôl „k"-ig 25 hüvelyk [ $=65,9 \mathrm{~cm}]$ lesz az esés.

5. A Dezsőffy ôrnagy házánál lévő „p” ponttól a „k” pontig 18 hüvelyk [=47,4 cm] az esés, ami „q"-nál nagyon kevés, ezért ajánlott a „p” pontot 12 hüvelykkel [=31,6 cm] magasítani. Így a „p”-től a „k”-ig 30 hüvelyk [=79,0 cm], és a „p”-tôl a „q"ig, a kapu felé, ahol jelenleg csak 25 hüvelyk [=65,9 cm], a jövôben 37 hüvelyk [=97,4 cm] lesz az esés.

6.A „k” ponttól az összes víz az „L” pont felé folyik, ahol azonban csak 4 hüvelyk $[=10,5 \mathrm{~cm}]$ esés van, ezért az „L” pontot legalább 12 hüvelykkel
[=31,6 cm] mélyíteni kell. Ezáltal az „m” pont kb. 18 hüvelykkel [=47,4 cm] kerül magasabbra az „L”-nél, így az „m”-tôl is „n”-hez fognak folyni a vizek.

\section{Megjegyzés}

A már elkészült burkolattal rendelkezó Buda utcának az esése az „a” ponttól „d”-ig, a Kapuhoz 103 hüvelyk [=271 cm]. Az „a” ponttól „b”-ig 13 hüvelyk [=34,2 cm] a mélyülés, „c"-tôl „b”-ig viszont 18 hüvelyk [=47,4 cm]. Az „a” ponttól az „f”-ig a Szent Anna utcán keresztül 17 hüvelyk [=44,8 cm] az esés. Mivel azonban ebben az utcában a burkolat középen mélyül, ahhoz, hogy a megálló vizet tovább vezessük, a burkolatot az utca közepén még valamennyire mélyíteni ajánlott. 


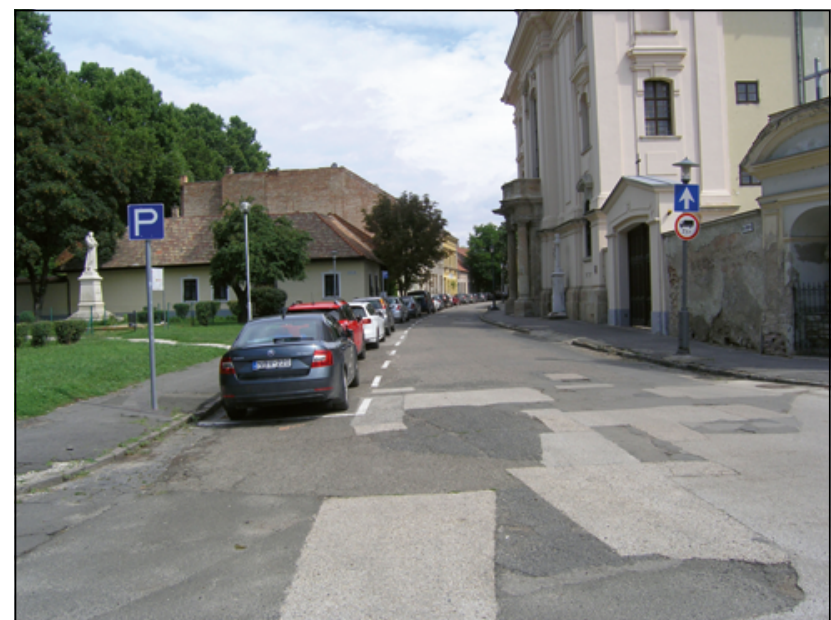

3. ábra. A Deák Ferenc utcának

$a, h$ "ponttól az „f" pont felé lejtố szakasza az „f" pontról

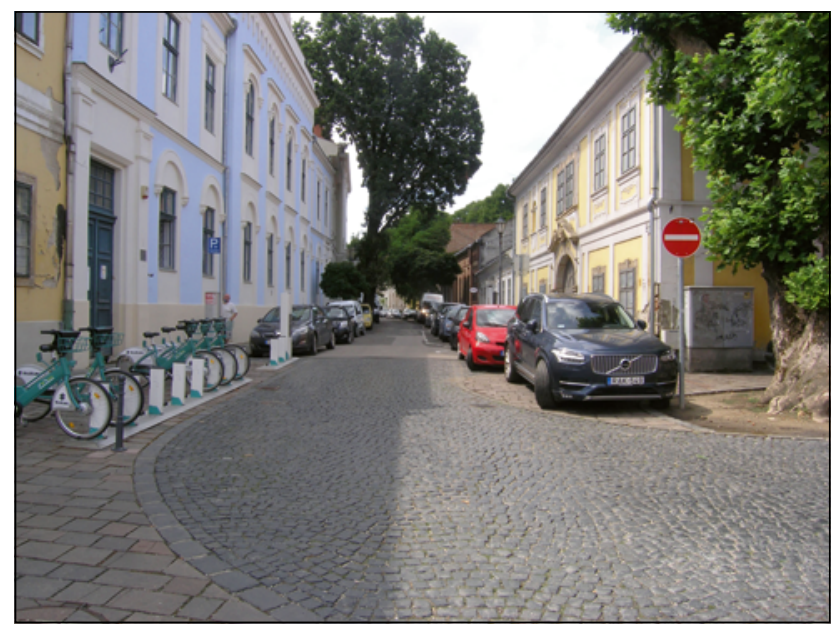

5. ábra. A Deák Ferenc utcának

$a$, , $h$ ponttól az „i” pont felé lejtô szakasza az ,i” pontról

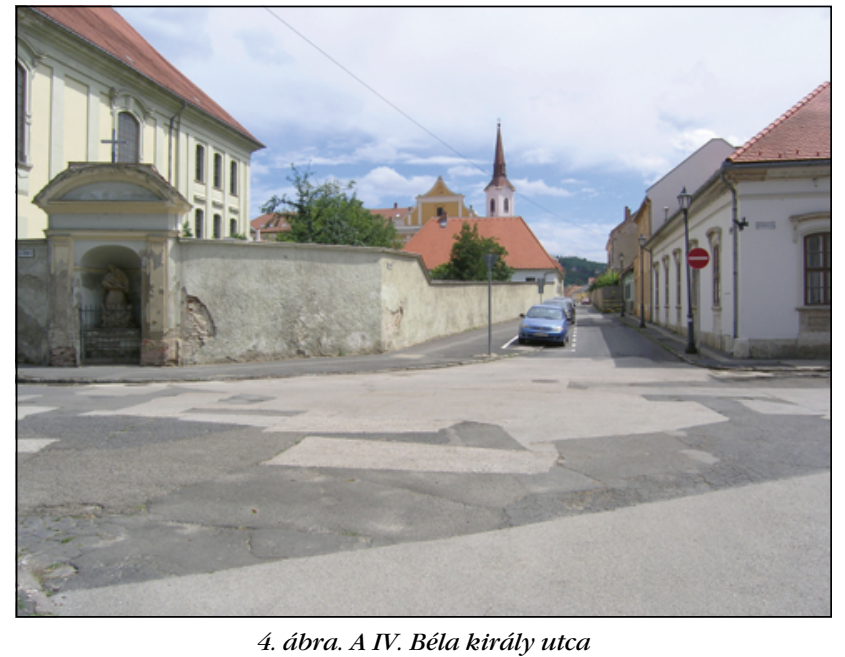

$a z$ „f ponttól az „s” pont és a „St. Anna utca” felé

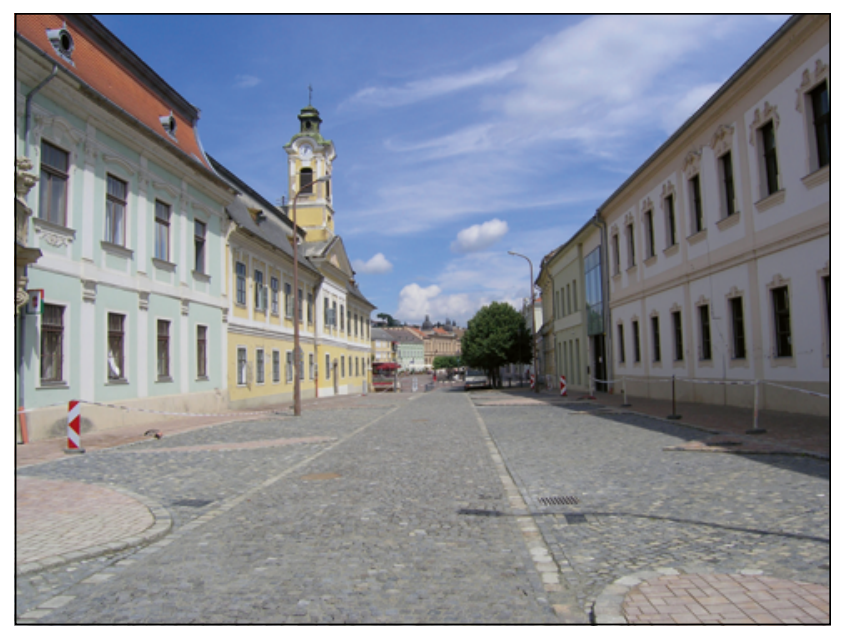

6. ábra. A Bottyán János utcának

$a$ „p" ponttól a ,k” pont felé lejtố szakasza

\section{A felmérési pontok helyei és betújeleinek feloldása}

(A korabeli utcanevek Prokopp 1981 alapján.)

a: A Buda utca és az attól a Halpiachoz vezető utca sarokpontja. Ma Kossuth Lajos utca és IV. Béla király utca keresztezôdése.

b: a Buda utcától kelet felé a városárokhoz menố elsố utca végpontja. Ma Simor János utca és Sissay köz sarok.

c: a Budautcától kelet felé,a árosárokhoz menô második utca végpontja. Ma Simor János utca és Magyar utca sarok.

d: Budai kapu (Thor) előtti mérési pont. Innen indult a postaút Dorog felé $(\mathrm{d}=$ Dorog $)$. A felmérés déli határpontja. Ma Hôsök tere.

f: a plébániatemplom melletti sarokpont. A templom elótt volt a Halpiac $(\mathrm{f}=$ Fischmarkt $)$. Ma Deák
Ferenc utca és IV. Béla király utca sarok.

g: a királyi város déli határán húzódó Városárok pontja ( $\mathrm{g}=$ Graben). Ma Jókai Mór utca és Árok utca sarok.

h: a Szent Ilona utca legmagasabb pontja $(h=$ Helena/höchste $)$. A felmérés kezdốpontja. Ma Deák Ferenc utca.

i: a Piactér délnyugati sarokpontja, a Szent Ilona utca kezdete $(\mathrm{i}=$ Ilona). Ma a Deák Ferenc utca kezdőpontja

k: a Tér (azaz a Piactér) legalacsonyabb pontja. A „k” betûjel valószínúleg az ott lévő keresztre utalás ( $\mathrm{k}=$ Kreutz), amely feltehetôen az 1710 körül állított Szentháromság-szoborra vonatkozik. Ma Széchenyi tér.

1: a felmérés északi határpontja, a Lốrinc kapu (Thor) elôtti mérési pont $(1=$ Lórinc $)$. A kapu a mellette lévố Szent Lôrinc-templomról kapta a nevét. Napjainkra jelentôsen átalakított területrész. Az egykori kapu helyét a burkolatban díszkövek jelzik.

m: a Piactér északi kezdốpontja ( $\mathrm{m}$ = Markt). Ma Széchenyi tér és Lốrinc utca sarok.

n: a csapadékvizek Dunába vezetésének helye, a vizsgált terület legalacsonyabb pontja $(\mathrm{n}=$ niedrig), ahol az „f” ponttól (ma IV. Béla király utca) jövő vizek a Dunába mennek.

o: a Piactértól a Buda utcához (Ofner Gasse), keleti irányba vezetô utca (o = Oriens). Ma az Arany János utca torkolata a Széchenyi térnél.

p: Dezsóffy ốrnagy háza elôtti pont, a Piactér felé vezetô utca legmagasabb pontja ( $\mathrm{p}=$ Platz). Ma Bottyán János utca 5., „Meszéna-ház”.

q: valószínúleg a Piactér északi felén lévô kút $(q=$ Quelle). A jelenlegi díszkút környékén volt, ma Széchenyi tér. 


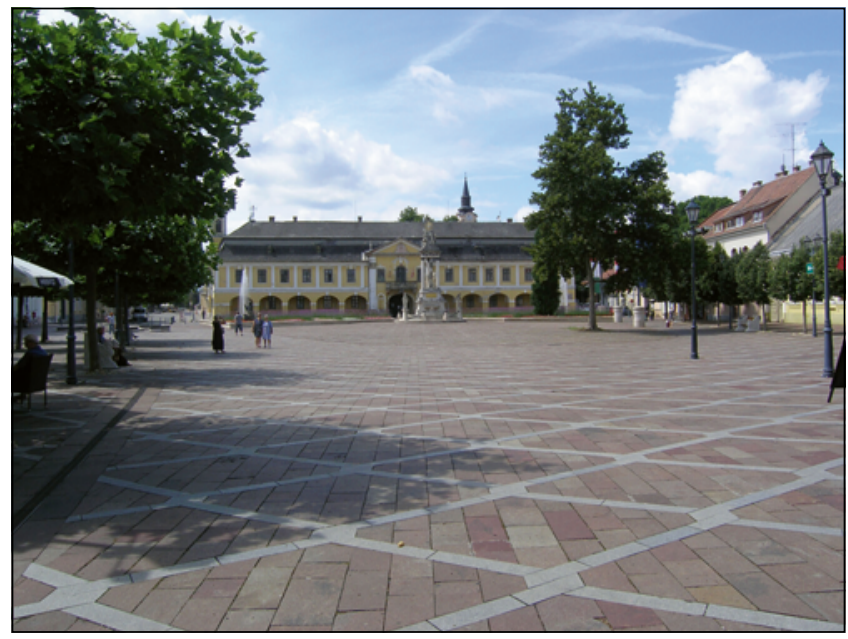

7. ábra. A Széchenyi tér a „q” pontról a ,k”, az „i” és az „o" pontok felé

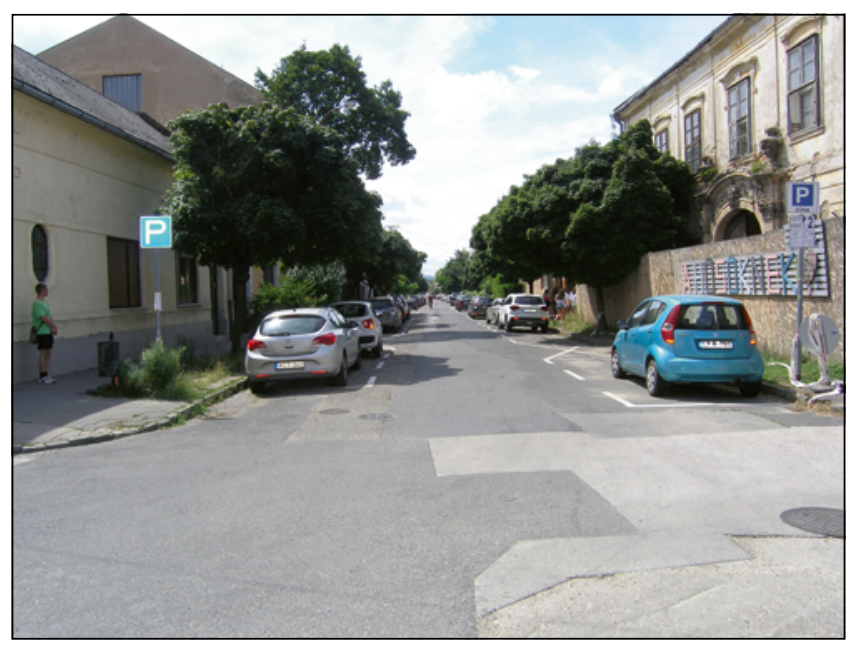

9. ábra. Az „s” ponttól a „g” pont felé lejtô Jókai Mór utca

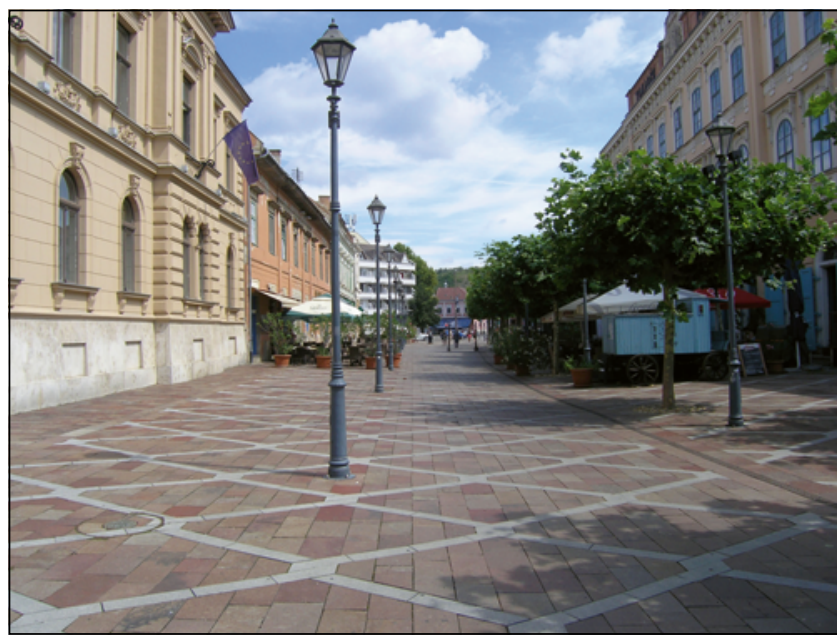

8. ábra. A Széchenyi térnek a "q" ponttól az „m” pont felé lejtô szakasza

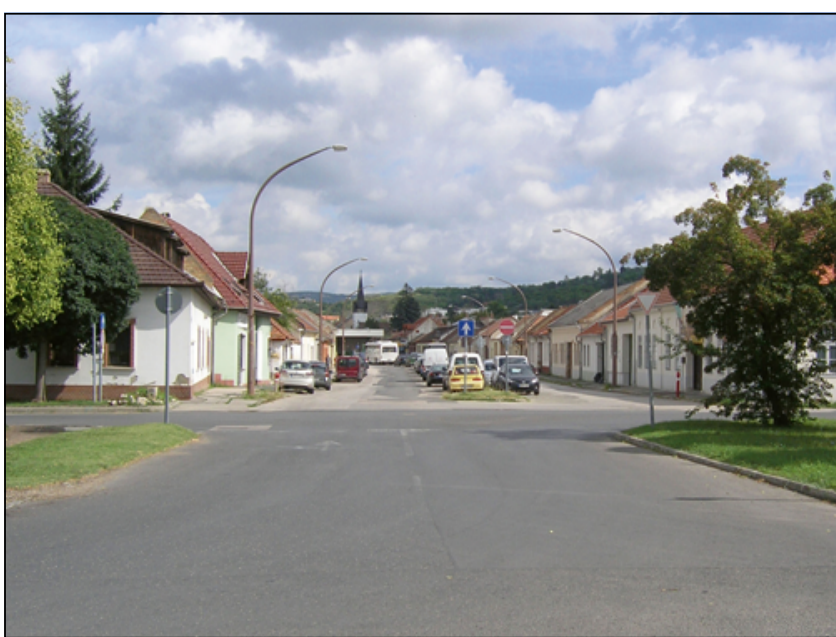

10. ábra. A városárok melletti terepfelszín a „c" ponttól $a$ „b” pont felé lejtett r: a nádorhelyettes háza mellett meglévő, burkolt vízlevezetô pontja ( $\mathrm{r}=$ Rinne). A telek a két párhuzamos utca közötti teljes sávot elfoglalta, az „r" pont a telek hátsó végénél volt. Ma Deák Ferenc utca.

s: Sándor báró háza elốtti pont (s = Sándor). Ma Jókai Mór utca és IV. Béla király utca sarok.

St. Annae Gässel: a Szent Anna utca kezdôpontja, nem kapott betújelet. Ma Mikszáth Kálmán utca és IV. Béla király utca sarok.

\section{Összefoglalás}

Esztergom városépítés-történetének egy érdekes, különleges epizódjaként értékelhető, hogy Mikoviny Sámuel, korának kiemelkedô hazai földmérôje és térképésze felmérte a város utcáit, és javaslatokat adott a csapadékvizek elvezetésének megoldására. Szakmatörténeti szempontból azért is fontos számunkra a most elôkerült dokumentum, mert Mikoviny munkásságának túlnyomó részét a Felvidéken, a mai Szlovákia területén folytatta. Esztergomi munkája eggyel növeli a mai Magyarország területén általa végzett, ismert munkák számát.

\section{Irodalom}

Csima Péter 2019. Mikoviny Sámuel, az épitész és tájalakitó. Építésügyi Tájékoztatási Központ, Budapest.

Deák Antal András 1987. A „Hungaria Nova” megrajzolója Mikoviny Sámuel 17001750. Vízügyi Dokumentációs Szolgáltató Leányvállalat, Budapest.

Prokopp Gyula 1981. Az esztergomi „királyi város" a XVIII. században. Múvészettörténeti Értesítô. 1. pp. 1-22.

Tóth Krisztina 2011. Esztergom szabad királyi város jegyzôkönyveinek regestái 1742-1748. Komárom-Esztergom Megyei Önkormányzat Levéltára Évkönyvei. 20. Esztergom.

Tóth Krisztina 2014. Esztergom szabad királyi város jegyzôkönyveinek regestái 1749-1755. Magyar Nemzeti Levéltár
Komárom-Esztergom Megyei Levéltára Évkönyvei. 22. Esztergom.

MNL KEML. Magyar Nemzeti Levéltár KomáromEsztergom Megyei Levéltára IV. 1001 a. Esztergom Szabad Királyi Város Tanácsának iratai 1749. 2. 10

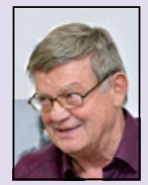

\section{Dr. Csima Péter} egyetemi tanár, tájépítész

SZIE Tájvédelmi és Tájrehabilitációs Tanszék csimapeter1@gmail.com

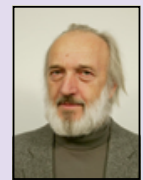

\section{Dr. Deák Antal} András térkép-és technikatörténész

Duna Múzeum deak.antal.andras@gmail.com 